Article

\title{
Modeling the Behavior of CFRP Strengthened Concrete Beams and Columns at Different Temperatures
}

\author{
Bassma Gawil $^{1, *}$, Hwai-Chung $\mathrm{Wu}^{1,2, *}$ and Abulgasem Elarbi ${ }^{1}$ \\ 1 Department of Civil and Environmental Engineering, Wayne State University, Detroit, MI 48202, USA; \\ ba4353@wayne.edu \\ 2 College of Civil Engineering, Fuzhou University, Fuzhou 350108, China \\ * Correspondence: ew2030@wayne.edu (B.G.); hwai-chung.wu@wayne.edu (H.-C.W.); Tel.: + 1-734-674-8408 \\ (B.G.); +1-313-577-0745 (H.-C.W.)
}

Received: 3 June 2019; Accepted: 23 January 2020; Published: 10 February 2020

check for updates

\begin{abstract}
The bonding of thin fiber-reinforced plastics (FRP) composites on the surface of concrete members has emerged as an effective method to increase both the strength and stiffness of concrete members. Although a large volume of experimental and numerical research has performed on existing concrete structures to increase their load carrying capacity, there appears to be less work reported on simulating the influence of temperature on the behavior of concrete structures. This study intends to examine the effects of changing temperature on the mechanical properties of FRP composites as well as deteriorated composites on the structural performance of FRP bonded concrete structures. The overall approach consists of computations using finite element models to simulate the structural behavior of FRP bonded beams and columns. Three-dimensional-extended finite element modeling X-FEM using ABAQUS-CAE v.6.13 program was performed to explore the influence of temperature of $\left(25^{\circ} \mathrm{C}\right.$, $100^{\circ} \mathrm{C}$ and $180^{\circ} \mathrm{C}$ ) on failure loads of FRP strengthened beams and columns with adhesive material. Additionally, the cohesive traction-separation damage model was use to model the delamination of FRP from the concrete. The flexural strength, mid-span deflection, crack patterns, failure loads, and mode of failure for the tested models were compared with the previous experimental study. The results show that a FEM results were in good agreement with experimental results. The flexural strength decreases with temperature rise for FRP strengthened concrete beams. The high temperature $180{ }^{\circ} \mathrm{C}$ has an adverse influence on the compressive strength of the specimens. The way of FRP rupture in the simulation was similar to the mode that was observed during the experimental tests.
\end{abstract}

Keywords: abaqus; bond strength; concrete; crack propagation; extended finite element method (X-FEM); finite element analysis; FRP; room temperature; $100{ }^{\circ} \mathrm{C}$ and $180{ }^{\circ} \mathrm{C}$; strengthening

\section{Introduction}

One of the main causes of the deterioration of construction materials is due to external environmental conditions (temperature and humidity) [1]. Prolonged exposure or even short-term exposure to elevated temperatures will often produce irreversible physical and chemical changes within adhesives [1].

Deteriorated structures need repair to ensure proper functioning, and to prolong their usefulness [2]. Intact structures may also need modification because of design or construction errors, or to accommodate changes in use. To address this need, engineers have developed methods of strengthening techniques. Traditional strengthening and retrofitting techniques that use steel and cementitious materials do not always provide the most appropriate solutions [2,3]. 
During the past decade, a large body of research has been directed towards better understanding the behavior of civil infrastructures employing FRP composites, and for the development of design guidelines. Nevertheless, these studies have generally ignored or marginally evaluated the reaction of structural systems using FRP to the environments, most importantly temperature changes, to which civil engineering structures are subjected $[3,4]$.

Using an extensive array of instruments and field as well as laboratory tests, the short-term and long-term performances of four types of FRP composite bridge decks were recently evaluated [5]. The coefficient of thermal expansion and the level of temperature gradient were found to be higher than those of standard reinforced concrete decks [6]. Lack of attention to detailing and thermal characteristics of individual components as well as the entire FRP deck system can lead to build up of large thermal stresses, which can result in unexpected deformations and damage. To ensure satisfactory performance, thermal behavior and the resulting thermal stresses need to be incorporated into the design and detailing of panel-girder connections, field joints, and face sheet-core connection in sandwich type panels [7]. Temperature variation can effect composite behavior as a result of thermal expansion mismatch (for instance between the fiber and matrix or between the plies of different orientation). Further, the level of residual stress will depend on temperature variations [8].

Performance of FRP strengthened structures depends on the efficiency of the bond [2,9], which is directly affected by the roughness of the surface [2]. Preventive measures must be carried out to assure adequate bonding. For instance, proper substrate preparation and on-site tests should be executed to verify that each resin batch has sufficient bond with the concrete substrate [10]. The bond strength decreases when the temperature increases [1].

This study focuses on the behavior of FRP bonded concrete beams and columns under various temperature environments (room temperature, 100 and $\left.180{ }^{\circ} \mathrm{C}\right)\left(77,212\right.$, and $356^{\circ} \mathrm{F}$ ), using finite element modelling by ABAQUS-CAE v.6.13 program. We focused on hot temperature environments to investigate the applications of FRP systems in many hot and humid regions around the world.

Finite element analysis numerically models the behavior of structures to corroborate with the experimental data. Finite element analysis, as used in structural engineering, determines the overall behavior of a structure by dividing it into a number of simple elements, each of which has well-defined mechanical and physical properties. When analyzing composite structures using finite elements we need to supply to the software appropriate input data for the material being used. Typically, for composites, we shall need moduli and strength of the single plies that constitute a laminate. Occasionally we may input the laminate properties directly [11].

In recent years, the extended finite element method [12] has emerged as a powerful numerical procedure for the analysis of crack problems. The extended finite element method was developed to ease difficulties in solving problems with localized features that are not efficiently resolved by mesh refinement. One of the initial applications was the modelling of fractures in a material [13]. In this original implementation, discontinuous basis functions are added to standard polynomial basis functions for nodes that belonged to elements that are intersected by a crack to provide a basis that included crack opening displacements [13].

\section{Literature Review}

Elarbi [2] studied the effects of changing hygrothermal conditioning cycles on the durability performance of FRP strengthened concrete beams and columns. The study encompassed the long term impact of moisture, high temperature $\left(100^{\circ} \mathrm{C}, 180^{\circ} \mathrm{C}\right)$.

The flexural strength of plain concrete beams changed, due to subjecting to $100{ }^{\circ} \mathrm{C}$ temperature, the changes and magnitudes of flexural strength depended on the number of cycles. By exposing to $180^{\circ} \mathrm{C}$, both the flexural and compressive strength decreased and the FRP delamination was the dominant mode of failure for all beam specimens. The presence of humidity has some influence on the strength of concrete beams and columns especially at $180^{\circ} \mathrm{C}$. 
Di Tommaso et al. [14] investigated the influence of temperature in three point bending tests at temperatures ranging from $-100{ }^{\circ} \mathrm{C}\left(-212^{\circ} \mathrm{F}\right)$ up to $40^{\circ} \mathrm{C}\left(104^{\circ} \mathrm{F}\right)$. Relative to the failure load at room temperature, decreasing failure loads were found both for increasing and decreasing temperatures. The influence of temperature on small scale three point bending tests was investigated by Klamer et al. [15]. In these tests, an increasing failure load was found with increasing temperatures, until around the glass transition temperature of the adhesive $\left(62{ }^{\circ} \mathrm{C}\right.$ or $\left.144^{\circ} \mathrm{F}\right)$. For higher temperatures, a decreasing failure load was found due to the changed type of failure.

Mavalar et al. [16] studied the short-term effects of temperature, moisture, and chloride content on the CFRP adhesion using pull-off tests. They found that the bond strength decreased significantly at high temperatures $[1,16]$. Tadeu et al. [17] performed several double-lap shear tests on concrete specimens externally bonded with steel plates. The authors noted a significant reduction of the failure load by increasing the temperature and reported failures in the adhesive for temperatures higher than $30^{\circ} \mathrm{C}\left(\right.$ or $\left.86^{\circ} \mathrm{F}\right)$.

Obaidat et al. [18] presented a finite element analysis which was validated against laboratory tests of eight beams. All beams were loaded under four point bending but differed in the length of the carbon fiber reinforced plastic (CFRP) plate. The commercial numerical analysis tool ABAQUS was used. The analyses results demonstrated similar results with the experimental data regarding load-displacement response, crack pattern, and debonding failure mode when the cohesive bond model is used. Mohammadi et al. [19] studied a numerical analysis method using XFEM implemented in ABAQUS to model FRP intermediate crack debonding failure which was started at the tip of a flexural crack in a plain concrete beam specimen. The numerical analysis has given stiffer results compared with experimental results [19].

Therefore, this study will focus on the three-dimensional extended finite element modeling $x$-FEM (offers significant benefits in the numerical modeling of crack propagation) using ABAQUS-CAE v.6.13 program was performed to explore the influence of temperature of $\left(25,100\right.$, and $\left.180^{\circ} \mathrm{C}\right)$ on failure loads of FRP strengthened beams and columns with adhesive material. Additionally, the cohesive traction-separation damage model was used to model the delamination of FRP from the concrete, and a comparison was made between the numerical results and the experimental results [2].

\section{Finite Element Modelling}

The three-dimensional nonlinear extended finite element method (X-FEM) has been utilized to model the behavior of concrete beams and columns subjected to different temperatures numerically. The ABQUS CAE finite element software was adopted in this study to simulate and predict the load -displacement response of the strengthened concrete beams and columns at room temperature "RT", $100{ }^{\circ} \mathrm{C}$, and $180^{\circ} \mathrm{C}$.

\subsection{FRP Strengthened Concrete Beams at Room Temperature (RT)}

A three-dimensional nonlinear (X-FEM) was created to study the performance of FRP strengthened concrete beams with dimensions of $406\left(16^{\prime \prime}\right) \times 109\left(4.3^{\prime \prime}\right) \times 104 \mathrm{~mm}\left(4.1^{\prime \prime}\right)$ (length, width, and height) respectively. The beam was modeled as simply supported over a $305 \mathrm{~mm}\left(12^{\prime \prime}\right)$ span and loaded at the middle of the span. The model consisted of two parts, the first part represented the concrete beam while the second part epitomized the FRP sheet. Two types of material properties were input to the ABAQUS-CAE. For the first part (concrete), the section type was selected "deformable", the shape was chosen "Solid", and the type was "Extrusion". The element has been considered as an elastic-isotropic material, and the section was chosen as Solid/Homogenous. The Poisson's ratio was assumed to be 0.18 , and concrete density equal to $2.4 \times 10^{-6} \mathrm{Kg} / \mathrm{mm}^{3}\left(0.0867 \mathrm{lb} / \mathrm{in}^{3}\right)$. The average compressive strength of experimental test results was $38 \mathrm{MPa}(5502 \mathrm{psi})$ after 28 days, The Max. Principal Stress was used of $2.45 \mathrm{MPa}(355 \mathrm{psi})$, and the modulus of elasticity of concrete was $2.92 \times 10^{4} \mathrm{MPa}\left(4.23 \times 10^{6} \mathrm{psi}\right)$.

The concrete damaged plasticity "CDP" is one of the most popular concrete models used for simulation of concrete behavior in Abaqus. For a full definition of the CDP model in Abaqus the 
following obligatory parameters should be input: the ratio $\mathrm{fb} 0 / \mathrm{fc} 0$ of biaxial compressive yield stress to uniaxial compressive yield stress, the ratio $K$ of the second stress invariant on the tensile meridian to that on the compressive meridian for the yield function, dilation angle, and the viscosity parameter $[20,21]$ (see Table 1).

Table 1. CDP model parameters. (Class notes. Finite Element Analysis Lecture\#3. Lawrence Tech. University, 2010 [20]. Michal and Andrzej, 2015 [21]).

\begin{tabular}{cc}
\hline The Parameter & The Value \\
\hline Dilation angle [degrees] & 35 \\
Viscosity parameter & 0 \\
Eccentricity & 0.1 \\
$\mathrm{fb} 0 / \mathrm{fc} 0$ & 1.16 \\
$\mathrm{~K}$ & 0.67 \\
\hline
\end{tabular}

For FRP "part 2", elastic isotropic behavior up to failure was assumed. Poisson's ratio was assumed to be 0.3 . The section was solid and Homogeneous. The mechanical properties of FRP were provided by the manufacture (see Table 2).

Table 2. SikaWrap Hex 113C carbon fiber fabric properties. Elarbi, 2011 [2].

\begin{tabular}{lc}
\hline Typical Data & \multicolumn{1}{c}{ SikaWrap Hex 113C Carbon Fiber } \\
\hline Color & Black \\
Primary fiber direction & $0^{\circ} / 90^{\circ}(\mathrm{bi}$-directional $)$ \\
Weight per square yard & $196 \mathrm{~g} / \mathrm{m}^{2}(5.7 \mathrm{oz})$ \\
\hline & Fiber Properties \\
\hline Tensile Strength & $3450 \mathrm{MPa}\left(5 \times 10^{5} \mathrm{psi}\right)$ \\
Tensile Modulus & $230,000 \mathrm{MPa}\left(33.4 \times 10^{6} \mathrm{psi}\right)$ \\
Elongation & $1.5 \%$ \\
Density & $1.8 \mathrm{~g} / \mathrm{cc}\left(0.065 \mathrm{lbs} . / \mathrm{in}^{3}\right)$ \\
Normal Thickness & - \\
\hline & Cured Laminate Properties Design Values * \\
\hline Tensile Strength & $456 \mathrm{MPa}(66,000 \mathrm{psi})$ \\
Tensile modulus & $41,400 \mathrm{MPa}\left(6.0 \times 10^{6} \mathrm{psi}\right)$ \\
Elongation at breaks & $1.2 \%$ \\
Thickness & $0.25 \mathrm{~mm}(0.01 \mathrm{in})$ \\
\hline
\end{tabular}

* Cured laminate properties with Sikadur Hex 300 Epoxy. Properties after standard post cure $21-24{ }^{\circ} \mathrm{C}\left(70-75^{\circ} \mathrm{F}\right)$ for 5 days, then 48 hours at $60^{\circ} \mathrm{C}\left(140^{\circ} \mathrm{F}\right)$.

The sections were meshed by size of 0.6 for concrete (1856 nodes, 1372 elements) and 0.3 for FRP (1620 nodes, 742 elements), the element type was selected as "3D Stress", and the mesh controls selected Hex, while the mesh technique has been considered as structured, see Figure 1.

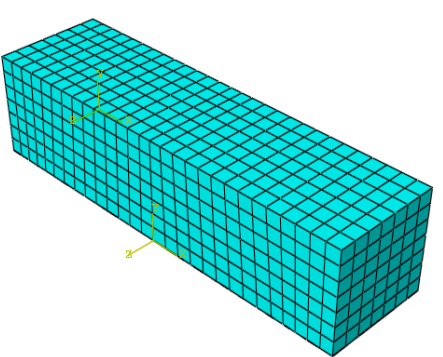

(a) Mesh of concrete by size (0.6)

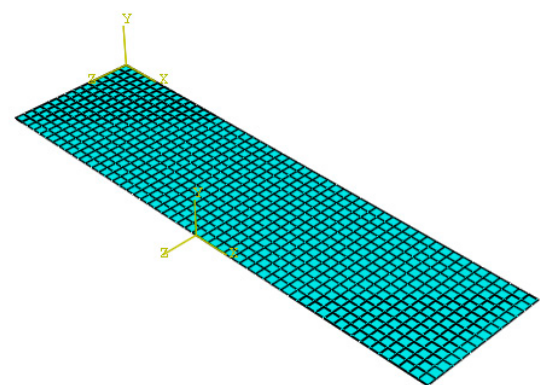

(b) Mesh of FRP by size (0.3)

Figure 1. Mesh of concrete beam and FRP strengthening sheet. (a) Mesh of concrete by size (0.6); (b) Mesh of FRP by size (0.3). 
To connect the two parts, the type of constraint that has been used was surface-to-surface contact, the concrete beam was designated as the master surface and the FRP was selected to be the slave surface. Contact bonding is supported in the cohesive behavior option of the contact interaction property, see Table 3 for adhesive properties.

Table 3. Adhesive Properties.

\begin{tabular}{|c|c|c|}
\hline The Property & The Value & \\
\hline E: Young's Modulus of adhesive & $\begin{array}{l}\text { 17.24 GPa } \\
\left(2.5 \times 10^{6} \mathrm{psi}\right) \\
\text { Elarbi, 2011 [2] }\end{array}$ & \\
\hline G: Shear Modulus of adhesive & $\begin{array}{l}0.665 \mathrm{GPa} \\
(96,450.1 \text { psi) } \\
\text { Obaidat et al., } 2010[18]\end{array}$ & \\
\hline t: Thickness of adhesive & $0.1 \mathrm{~mm}(0.004 \mathrm{in})$ & Estimated \\
\hline Stiffness Coefficients & $\begin{array}{l}\mathrm{Knn}=\mathrm{E} / \mathrm{t}=6.25 \times 10^{8} \\
\mathrm{Kss}=\mathrm{G} / \mathrm{t}=2.411 \times 10^{7} \\
\mathrm{Ktt}=\mathrm{G} / \mathrm{t}=2.411 \times 10^{7}\end{array}$ & \\
\hline Cohesive Strength & $\begin{array}{l}6 \mathrm{MPa}(870.23 \text { psi) } \\
\text { Mikamia et al., } 2015 \text { [22] }\end{array}$ & \\
\hline Shear Strength & $2.84 \mathrm{MPa}(406.11 \mathrm{psi})$ & $\begin{array}{l}\tau \max =1.46 \mathrm{Ga}^{0.165} \mathrm{fct}^{1.033} \text { Obaidat } \\
\text { et al., } 2010[18] \\
=1.46\left(0.665^{0.165}\right) 2.03^{1.033} \\
\text { fct is concrete tensile strength } \\
=0.33 \mathrm{fc}^{\prime}=2.03 \mathrm{MPa}\end{array}$ \\
\hline G: Fracture Energy & $\begin{array}{l}91.8 \mathrm{~g} / \mathrm{mm}(5.14 \mathrm{lb} / \mathrm{in}) \\
\text { (Estimated) }\end{array}$ & $\begin{array}{l}=\left(12 \mathrm{P}^{2} \mathrm{a}^{2}\right) /\left(\mathrm{E} \mathrm{h}^{3} \mathrm{~B}^{3}\right) \text { Dri and } \\
\text { Restrepo, 2011 [23] } \\
\text { Where } \mathrm{P} \text { is maximum experimental } \\
\text { load, a corresponds to the precrack } \\
\text { length, } \mathrm{h} \text { is the height of the sample, } \\
\text { and } \mathrm{B} \text { is the width of the samples. }\end{array}$ \\
\hline
\end{tabular}

The cohesive traction-separation damage model was use to model the delamination of FRP from the concrete.

For flexural strength, the concrete beam model was tested by center-point loading according to ASTM C293, whereas the effective span length was three times of the beam depth and the distance from the center of the support to the beam edge was $50 \mathrm{~mm}\left(2^{\prime \prime}\right)$ each side. The load was applied as a static pressure load and the type of boundary conditions has been selected "displacement/rotation." One support was considered as a pin and the other is a roller, see Figure 2.

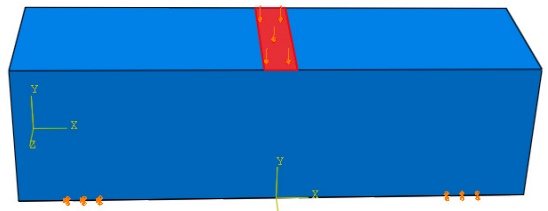

(a) Static Pressure Load

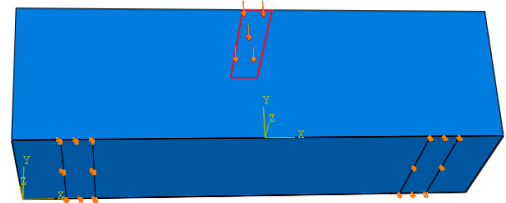

(b) Boundary Conditions

Figure 2. Load and boundary conditions of FRP strengthened concrete beam model. (a) Static Pressure Load; (b) Boundary Conditions.

\subsection{FRP Strengthened Concrete Beams at $100^{\circ} \mathrm{C}$}

The same procedures that were performed to model FRP strengthened concrete beams at RT have been followed to obtain the numerical results of strengthened concrete beams at $100^{\circ} \mathrm{C}$. The modulus of 
elasticity of concrete at $100^{\circ} \mathrm{C}$ was lower than the modulus of elasticity at RT based on the experimental data, see Table 4 . Table 5 shows concrete properties at $100^{\circ} \mathrm{C}$.

Table 4. Elastic properties for concrete (temperature dependent). (Class notes. Finite Element Analysis Lecture\#5. Lawrence Tech. University, 2010 [24]).

\begin{tabular}{ccc}
\hline Young's Modulus N/m & Poisson's Ratio & Temperature $\left({ }^{\circ} \mathbf{C}\right)$ \\
\hline $3.49 \times 10^{10}$ & 0.2 & 20 \\
$3.14 \times 10^{10}$ & 0.2 & 200 \\
$2.79 \times 10^{10}$ & 0.2 & 400 \\
\hline
\end{tabular}

Table 5. Concrete Properties at $100^{\circ} \mathrm{C}$.

\begin{tabular}{cc}
\hline The Property & The Value \\
\hline E100 Young's Modulus of concrete & $2.8 \times 10^{4} \mathrm{MPa}$ (4062000 psi) (Table 4) \\
\hline $\begin{array}{c}\text { No change in compressive strength (fc') (Ezekiel, et al., } \\
\text { 2013 [25]. Guo and Shi, 2011 [26]. Venkatesh, 2014 [27]) }\end{array}$ & $38 \mathrm{MPa}$ (5502 psi) \\
\hline $\begin{array}{l}\text { No change in Max. Principal Stress (Ezekiel, et al., 2013 } \\
\text { [25]. Guo and Shi, 2011 [26]. Venkatesh, 2014 [27]) }\end{array}$ & $2.45 \mathrm{MPa}$ (355 psi) \\
\hline
\end{tabular}

For contact property, the cohesive behavior was used, see Table 6 adhesive properties at $100{ }^{\circ} \mathrm{C}$.

Table 6. Adhesive properties at $100^{\circ} \mathrm{C}$.

\begin{tabular}{|c|c|c|}
\hline The Property & The Value & \\
\hline $\begin{array}{l}\text { E100: Young's Modulus of } \\
\text { adhesive }\end{array}$ & $\begin{array}{l}\text { 14.3 GPa } \\
\left(2.075 \times 10^{6} \text { psi) Elarbi, } 2011 \text { [2] }\right.\end{array}$ & \\
\hline $\begin{array}{l}\text { G100: Shear Modulus of } \\
\text { adhesive }\end{array}$ & $\begin{array}{l}425.6 \mathrm{MPa} \\
(61728.05 \mathrm{psi}) \text { Advanced Materials } \\
\text { Epibond }{ }^{\circledR} 100 \mathrm{~A} / \mathrm{B} \\
\text { High-temperature Epoxy } \\
\text { Structural Adhesive. Available } \\
\text { online: }[28]\end{array}$ & \\
\hline t: Thickness of adhesive & $0.1 \mathrm{~mm}$ (0.004 in) & Estimated \\
\hline Stiffness Coefficients & $\begin{array}{l}\mathrm{Knn}=\mathrm{E} / \mathrm{t}=5.187 \times 10^{8} \\
\mathrm{Kss}=\mathrm{G} / \mathrm{t}=1.5432 \times 10^{7} \\
\mathrm{Ktt}=\mathrm{G} / \mathrm{t}=1.5432 \times 10^{7}\end{array}$ & \\
\hline Cohesive Strength & $\begin{array}{l}1.2 \mathrm{MPa}(174.04 \text { psi) Mikamia et al., } \\
2015 \text { [22] }\end{array}$ & \\
\hline Shear Strength & 2.64 MPa (382.89 psi) & $\begin{array}{l}\tau \max =1.46 \mathrm{Ga}^{0.165} \mathrm{fct}^{1.033} \text { Obaidat et al., } \\
2010[18] \\
=1.46\left(0.4256^{0.165}\right) 2.03^{1.033} \\
=2.64 \mathrm{MPa}(382.89 \mathrm{psi})\end{array}$ \\
\hline Fracture Energy $(\mathrm{G})$ & $\begin{array}{l}70.7 \mathrm{~g} / \mathrm{mm}(3.96 \mathrm{lb} / \mathrm{in}) \\
\text { (Estimated) }\end{array}$ & $\begin{array}{l}=\left(12 \mathrm{P}^{2} \mathrm{a}^{2}\right) /\left(\mathrm{E} \mathrm{h}^{3} \mathrm{~B}^{3}\right) \text { Dri and Restrepo, } \\
2011[23] \\
\text { Where } \mathrm{P} \text { is maximum experimental load } \\
100{ }^{\circ} \mathrm{C} \text {, a is correspond to the precrack } \\
\text { length } 100{ }^{\circ} \mathrm{C}, \mathrm{h} \text { is the height of the } \\
\text { samples, and } \mathrm{B} \text { is the width of the sample. }\end{array}$ \\
\hline
\end{tabular}




\subsection{FRP Strengthened Concrete Beams at $180^{\circ} \mathrm{C}$}

The same procedures that were performed to model FRP strengthened concrete beams at RT and $100{ }^{\circ} \mathrm{C}$ have been followed to obtain the numerical results of strengthened concrete beams at $180{ }^{\circ} \mathrm{C}$. As shown in Table 7.

Table 7. Concrete Properties at $180^{\circ} \mathrm{C}$.

\begin{tabular}{cc}
\hline The Property & The Value \\
\hline E180 Young's Modulus of concrete & $2.67 \times 10^{4} \mathrm{MPa}(3,873,000$ psi) (Table 4) \\
\hline $\begin{array}{l}\text { No change in compressive strength (fc') (Ezekiel, et al., } \\
\text { 2013 [25]. Guo and Shi, 2011 [26]. Venkatesh, 2014 [27]) }\end{array}$ & $38 \mathrm{MPa}$ (5502 psi) \\
\hline $\begin{array}{l}\text { No change in Max. Principal Stress (Ezekiel, et al., 2013 } \\
\text { [25]. Guo and Shi, 2011 [26]. Venkatesh, 2014 [27]) }\end{array}$ & $2.45 \mathrm{MPa}$ (355 psi) \\
\hline
\end{tabular}

For contact property, the cohesive behavior was used. Table 8 shows adhesive properties at $180{ }^{\circ} \mathrm{C}$.

Table 8. Adhesive Properties at $180^{\circ} \mathrm{C}$.

\begin{tabular}{|c|c|c|}
\hline The Property & The Value & \\
\hline $\begin{array}{l}\text { E180: Young's Modulus of } \\
\text { adhesive }\end{array}$ & $\begin{array}{l}9825 \mathrm{MPa} \\
\left(1.425 \times 10^{6} \text { psi) Elarbi, } 2011 \text { [2] }\right.\end{array}$ & \\
\hline $\begin{array}{l}\text { G180: Shear Modulus of } \\
\text { adhesive }\end{array}$ & $\begin{array}{l}219.4 \mathrm{MPa} \\
(31,828.52 \text { psi) Advanced Materials } \\
\text { Epibond }{ }^{\circledR} 100 \text { A/B } \\
\text { High-temperature Epoxy } \\
\text { Structural Adhesive. Available } \\
\text { online: [28] }\end{array}$ & \\
\hline t: Thickness of adhesive & $0.1 \mathrm{~mm}$ (0.004 in) & Estimated \\
\hline Stiffness Coefficients & $\begin{array}{l}\mathrm{Knn}=\mathrm{E} / \mathrm{t}=3.563 \times 10^{8} \\
\mathrm{Kss}=\mathrm{G} / \mathrm{t}=7.95713 \times 10^{6} \\
\mathrm{Ktt}=\mathrm{G} / \mathrm{t}=7.95713 \times 10^{6}\end{array}$ & \\
\hline Cohesive Strength & $\begin{array}{l}0.8 \mathrm{MPa}(116.03 \text { psi) Mikamia et al., } \\
2015 \text { [22] }\end{array}$ & \\
\hline Shear Strength & 2.36 MPa (342.29 psi) & $\begin{array}{l}\boldsymbol{\tau}_{\max }=1.46 \mathrm{Ga}^{0.165} \mathrm{fct}^{1.033} \text { Obaidat et al., } \\
2010[18] \\
=1.46\left(0.21945^{0.165}\right) 2.03^{1.033} \\
=2.36 \mathrm{MPa}(342.29 \mathrm{psi})\end{array}$ \\
\hline Fracture Energy $(\mathrm{G})$ & $\begin{array}{l}62.5 \mathrm{~g} / \mathrm{mm}(3.5 \mathrm{lb} / \mathrm{in}) \\
\text { (Estimated) }\end{array}$ & $\begin{array}{l}=\left(12 \mathrm{P}^{2} \mathrm{a}^{2}\right) /\left(\mathrm{E} \mathrm{h}^{3} \mathrm{~B}^{3}\right) \\
\text { Dri and Restrepo, } 2011 \text { [23] } \\
\text { Where } \mathrm{P} \text { is maximum experimental load } \\
180^{\circ} \mathrm{C} \text {, a is correspond to the precrack } \\
\text { length } 180{ }^{\circ} \mathrm{C}, \mathrm{h} \text { is the height of the } \\
\text { samples, and } \mathrm{B} \text { is the width of the sample. }\end{array}$ \\
\hline
\end{tabular}

\section{Finite Element Modelling for Columns}

Likewise, with some differences to the procedures which have been followed to simulate the FRP strengthened concrete beam, the FRP strengthened column has been treated. A 3D nonlinear extended finite-element analysis of the FRP-strengthened column was carried out using the ABAQUS/CAE.

\subsection{FRP Strengthened Concrete Columns at Room Temperature (RT)}

The model was divided into two parts. While the first part represented the 3-D cylindrical concrete column with a dimension of $20 \mathrm{~mm}\left(8^{\prime \prime}\right)$ height and $10 \mathrm{~mm}\left(4^{\prime \prime}\right)$ diameter, the second part dealt with the FRP, see Figure 3. The properties have been selected to be the same as those for the FRP strengthened 
concrete beam simulation. The damage evaluation has been selected to be the same as those for the FRP strengthened concrete beam simulation. The mesh seed was chosen edge by size 0.4 for FRP (1344 nodes, 640 elements) and 0.69 for concrete (1573 nodes, 1440 elements), see Figure 4 . The mesh controls selected as Hex-dominated for FRP and Hex for concrete, while the mesh technique has been considered as structured and the element type was 3-D stress for both concrete and FRP.

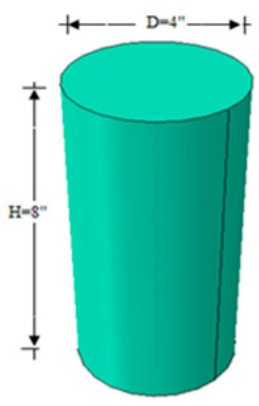

Concrete

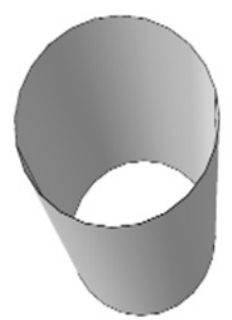

FRP

Figure 3. 3-D strengthened concrete column model.

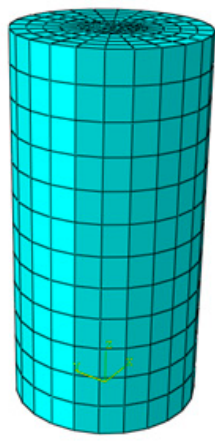

Concrete

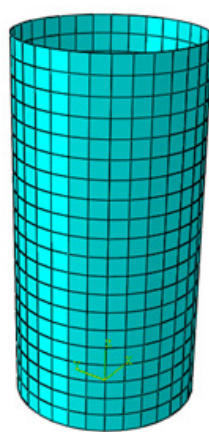

FRP

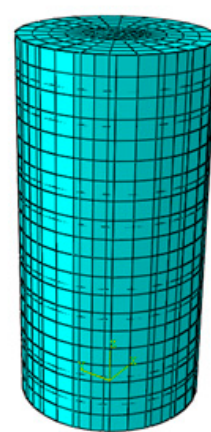

Concrete + FRP

Figure 4. Mesh of the FRP concrete column model.

To connect the two parts, the type of constraint that has been used was surface-to-surface contact. The concrete column was designated as the master surface, while the FRP has been selected to be the slave surface. Contact bonding is enabled in the cohesive behavior option of the contact interaction property. The load has been selected as a static pressure on the upper surface and the type of boundary conditions at the bottom surface was chosen as the displacement/rotation, see Figure 5.

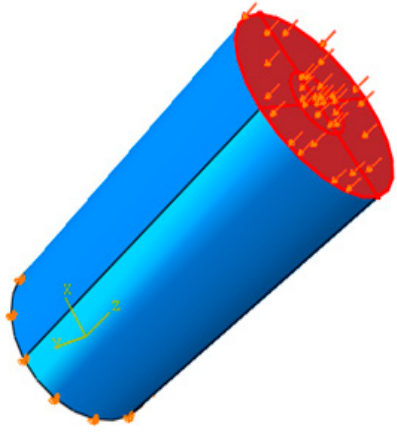

(a) Static Pressure Load

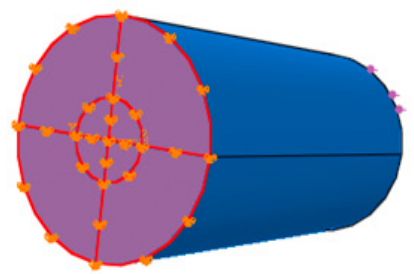

(b) Boundary Conditions

Figure 5. Load and boundary conditions of FRP strengthened column model. (a) Mesh of concrete by size; (b) Mesh of FRP by size. 


\subsection{FRP Strengthened Concrete Columns at $100^{\circ} \mathrm{C}$}

The same procedures that were performed to model FRP strengthened concrete columns at RT have been followed to obtain the numerical results of strengthened concrete columns at $100{ }^{\circ} \mathrm{C}$. The modulus of elasticity of concrete at $100^{\circ} \mathrm{C}$ was lower than the modulus of elasticity at RT based on the experimental data, see Table 4 . Table 5 shows concrete properties at $100{ }^{\circ} \mathrm{C}$. For adhesive properties at $100{ }^{\circ} \mathrm{C}$, see Table 6 .

\subsection{FRP Strengthened Concrete Columns at $180^{\circ} \mathrm{C}$}

The same procedures that were performed to model FRP strengthened concrete columns at RT and $100{ }^{\circ} \mathrm{C}$ have been followed to obtain the numerical results of strengthened concrete column at $180^{\circ} \mathrm{C}$. Table 7 shows concrete properties at $180^{\circ} \mathrm{C}$. The adhesive properties at $180^{\circ} \mathrm{C}$ are shown in Table 8 .

\section{Finite Element Analysis Results and Discussion}

In this section, the behavior of FRP strengthened concrete beams and columns are discussed and the results were compared with the experimental investigations [2]. The extended finite element method was used to model the behavior of those elements numerically.

\subsection{FRP Strengthened Concrete Beams at Room Temperature (RT)}

By running the ABQUS-CAE software, the load started to increase by steps and the section began to deform until failure. The concrete crack began at the lowest point of the concrete beam almost at the center and propagated upward, followed by the delamination of the FRP and finally the FRP ruptured. The sequence of failure in the simulation was similar to that of the experimental tests, see Figure 6.

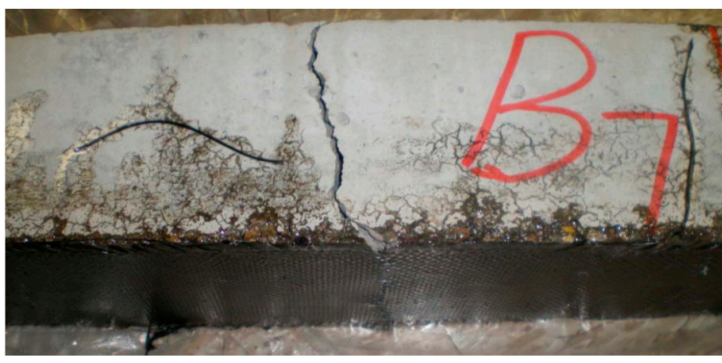

(a) Concrete flexural crack

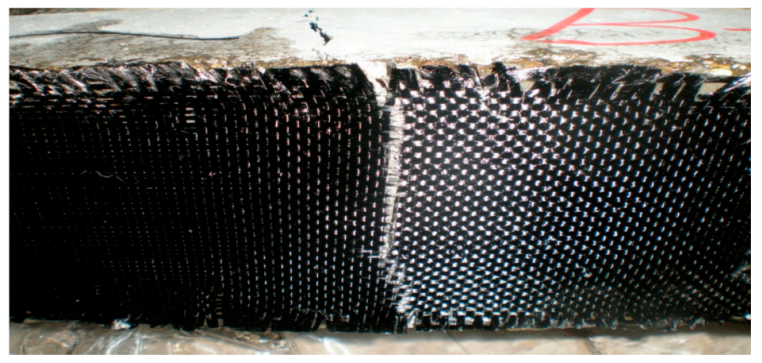

(b) FRP Rupture

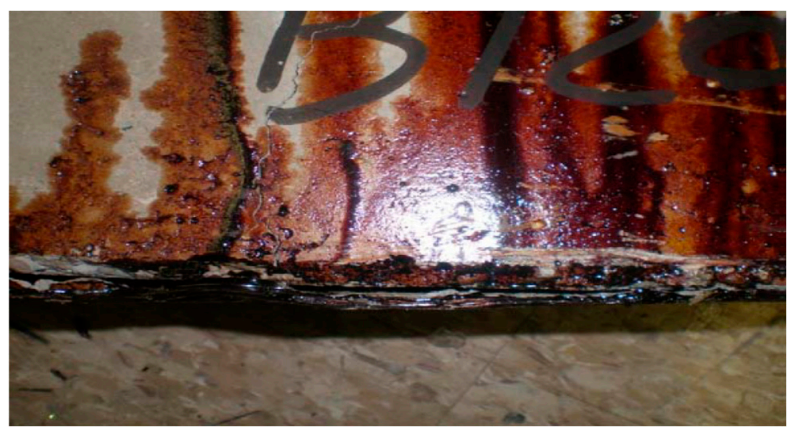

(c) FRP delamination

Figure 6. Concrete flexural crack, FRP rupture and delamination at experimental tests. Elarbi, 2011 [2].

The events of simulation loadings were depicted in Figure 7a. All loading stages are shown in Figure $7 \mathrm{~b}$.

As shown in Figure 7, the first concrete crack started when the external load reached $40.75 \%$ of the peak load and FRP delamination started when the external load reached $95.07 \%$ of the peak 
load. While the first rupture of CFRP started when the external load reached $99.63 \%$ of the peak load, the Max. Principal stress of CFRP reached the input $456 \mathrm{MPa}(66,000 \mathrm{psi})$ at rupture.

By comparing the simulated and experimental flexural load and mid-span deflection of FRP strengthened concrete beams at RT, the experimental results of flexural load were about $27 \%$ less than the numerical results, which means the finite element model has been successful in prediction FRP strengthened concrete beam failure load.

The maximum principal stress of concrete reached the input $2.813 \mathrm{MPa}(408 \mathrm{psi})$ at crack, and then gradually increased until the peak load. The failure changed above the FRP from failure in the concrete near the interface with the adhesive to failure exactly in the interface in between the concrete and the adhesive.

\section{1- Concrete Crack}

\section{Stage 1 (First Crack)}

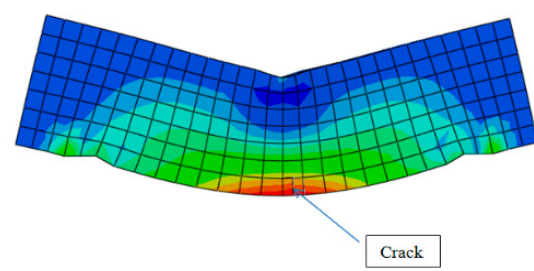

The first crack (stage 1) of concrete when the external load reached $40.75 \%$ of the peak load.

Stage 3

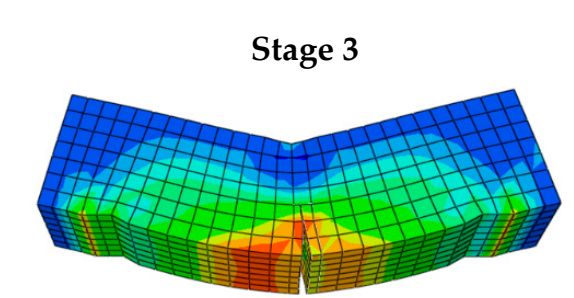

Extend the first crack of concrete (stage 3) when

the external load reached $65.95 \%$ of the peak load.

(a)

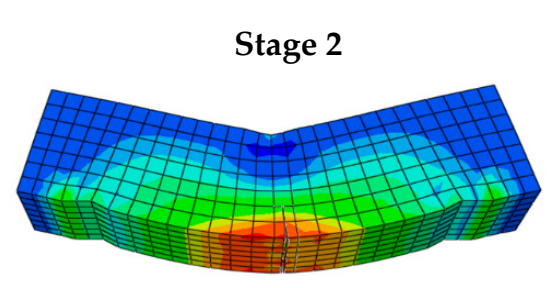

Extend the first crack of concrete (stage 2) when the external load reached $53.25 \%$ of the peak load.

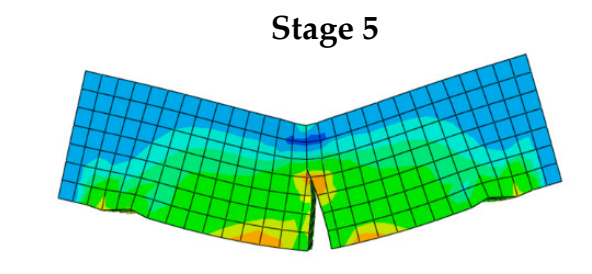

Extend the first crack of concrete (stage 5) when Extend the first crack of concrete (stage 6) when the the external load reached $91.77 \%$ of the peak load. external load reached $95.03 \%$ of the peak load.
Extend the first crack of concrete (stage 4) when the external load reached $78.03 \%$ of the peak load.

Figure 7. Cont. 
2- CFRP Delamination, Stage 7
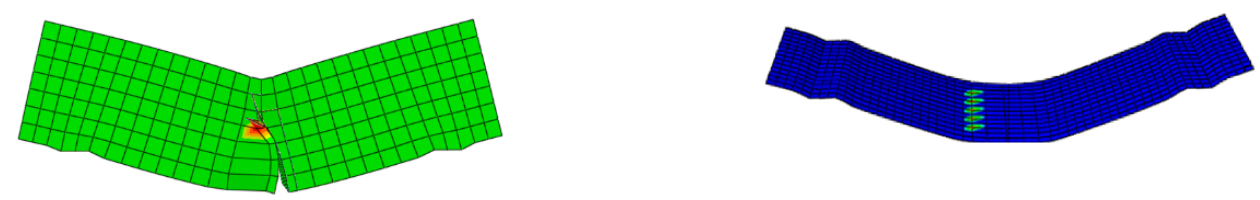

Extend the first crack of concrete (stage 7) when the external load reached $95.07 \%$ of the peak load.

FRP delamination started when the external load

\section{3- CFRP Rupture}
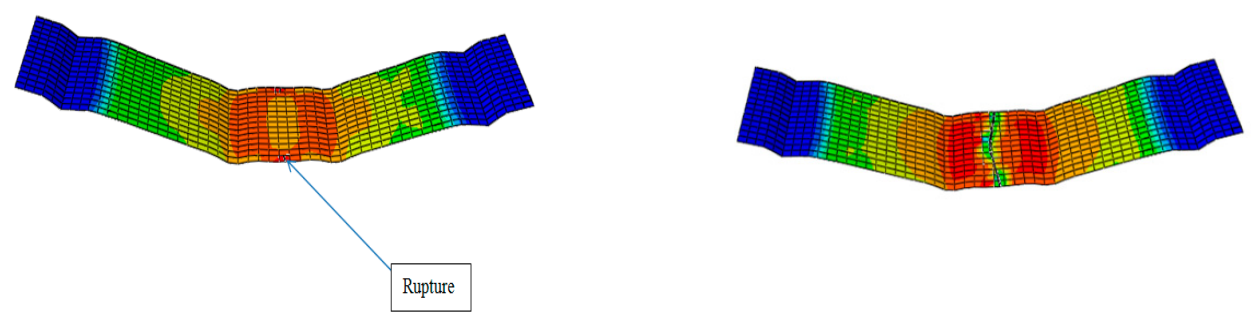

The first rupture of CFRP started when the The external load reached $99.64 \%$ of the peak load. external load reached $99.63 \%$ of the peak load.
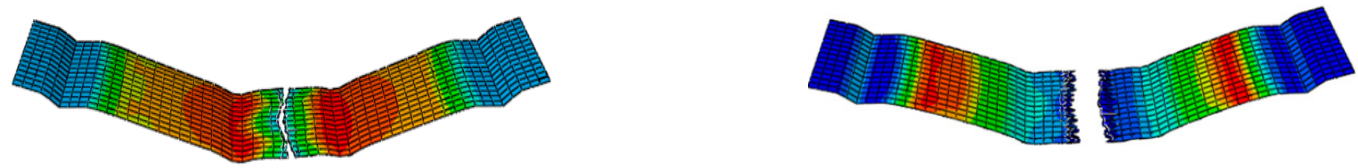

The external load reached $99.65 \%$ of the peak At peak load. load.

(a) The events of simulation loadings

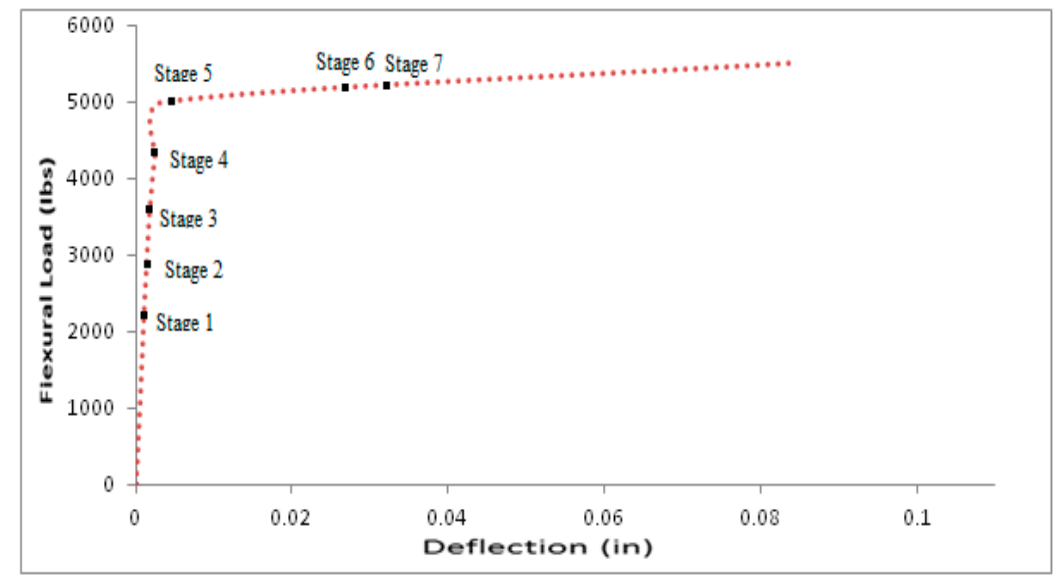

(b) The stages of concrete crack

Figure 7. Numerical flexural response of FRP strengthened concrete beams and the stages of concrete crack at RT. (a) The events of simulation loadings; (b) The stages of concrete crack.

\subsection{FRP Strengthened Concrete Beams at $100^{\circ} \mathrm{C}$}

The events of simulation loadings were depicted in Figure 8a. All loading stages were shown in Figure 8b. 


\section{Concrete Crack}

Stage 1 (First Crack)

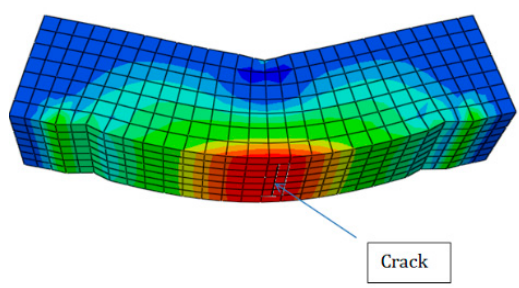

The first concrete crack started (stage 1) when the external load reached $40.75 \%$ of the peak load.

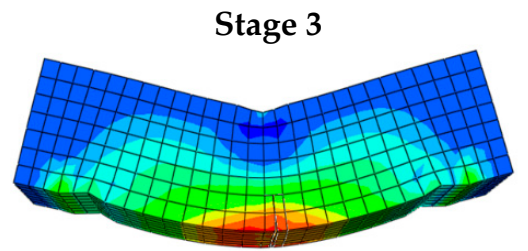

Extend the first crack of concrete (stage 3) when the external load reached $53.46 \%$ of the peak load.

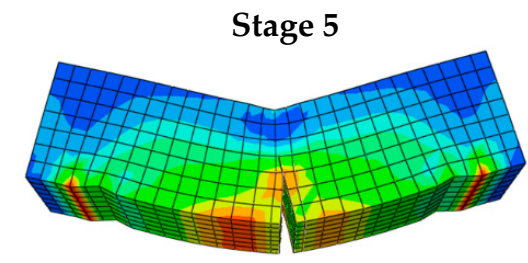

Extend the first crack of concrete (stage 5) when the external load reached $78.62 \%$ of the peak load.

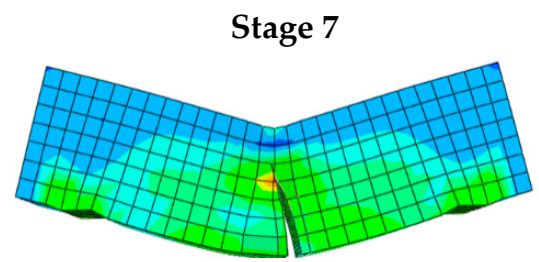

Extend the first crack of concrete (stage 7) when the external load reached $95.69 \%$ of the peak load.

Figure 8. Cont.
Extend the first crack of concrete (stage 2) when the external load reached $41.85 \%$ of the peak load.

Stage 4

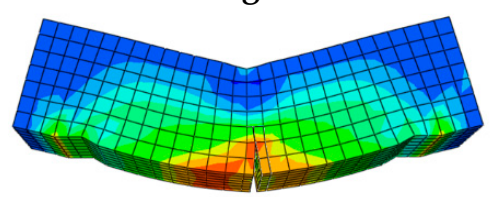

Extend the first crack of concrete (stage 4) when the external load reached $66.58 \%$ of the peak load.

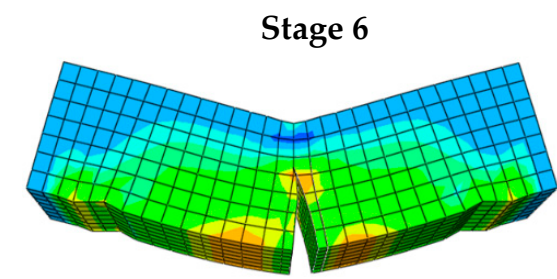

Extend the first crack of concrete (stage 6) when the external load reached $92.96 \%$ of the peak load.

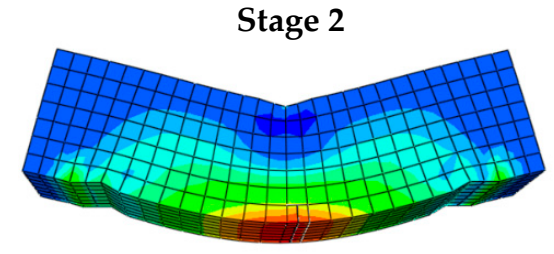




\section{CFRP Delamination}

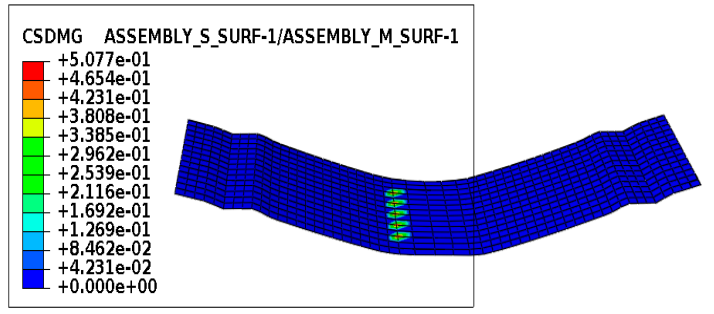

FRP delamination started when the external load reached $95.73 \%$ of the peak load.

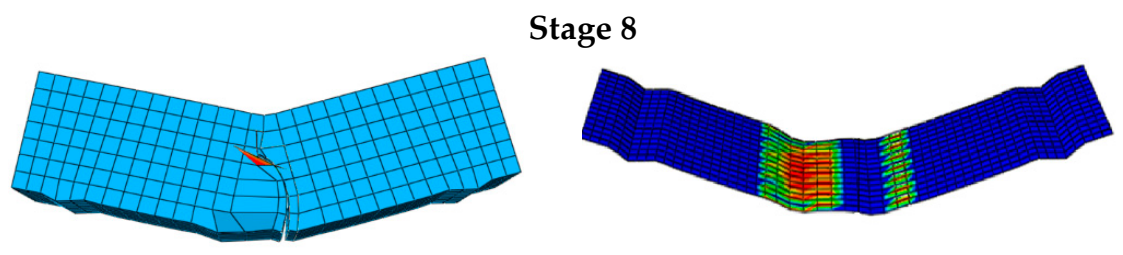

Extend the first crack of concrete (stage 8) when the external load reached $96.10 \%$ of the peak load. (a) The events of simulation loadings

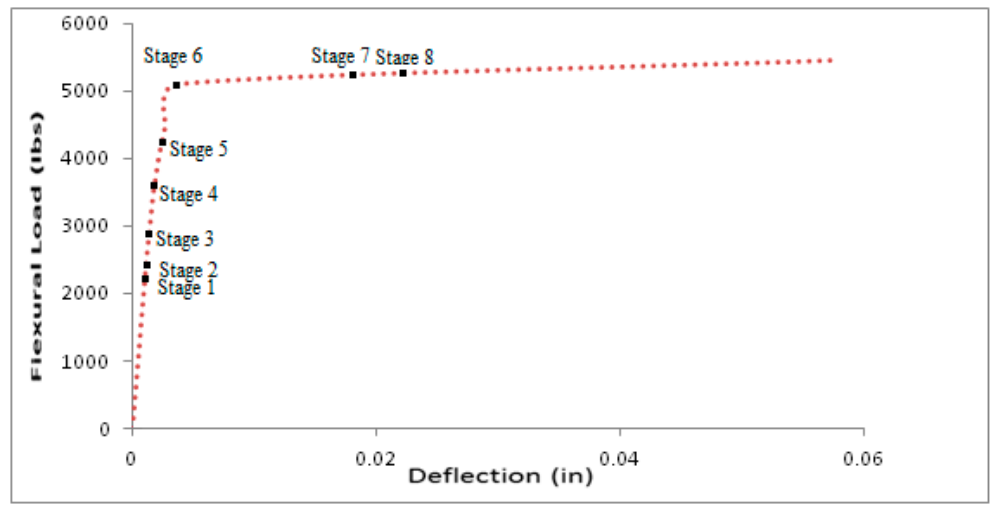

(b) The stages of concrete crack

Figure 8. Numerical flexural response of FRP strengthened concrete beams and the stages of concrete crack at $100{ }^{\circ} \mathrm{C}$. (a) The events of simulation loadings; (b) The stages of concrete crack.

As shown in Figure 8, the first concrete crack started when the external load reached $40.75 \%$ of the peak load. There is no rupture of FRP, and FRP delamination started when the external load reached $95.73 \%$ of the peak load.

Similarly, when compared the simulated and experimental flexural load and mid-span deflection of FRP strengthened concrete beams at $100{ }^{\circ} \mathrm{C}$, the experimental results of flexural load were about $6 \%$ less than the numerical results, which means the finite element model has been successful in prediction FRP strengthened concrete beam failure load. The Max. Principal stress of concrete reached the input Max. Principal stress of concrete $3.047 \mathrm{MPa}$ (442 psi) at crack, then gradually increased until the peak load. The cohesive strength decreases when the temperature increases. See Tables 3 and 6.

The failure changed the above FRP transition temperature from failure in the concrete near the interface with the adhesive to failure exactly in the interface in between the concrete and the adhesive.

\subsection{FRP Strengthened Concrete Beams at $180^{\circ} \mathrm{C}$}

The events of simulation loadings were depicted in Figure 9a. All loading stages are shown in Figure 9b. 


\section{Concrete Crack}

Stage 1 (First Crack)

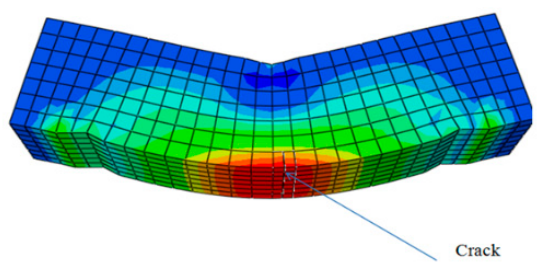

The first concrete crack started (stage 1) when the external load reached $41.88 \%$ of the peak load.

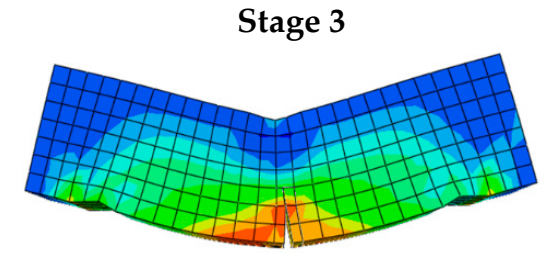

Stage 2

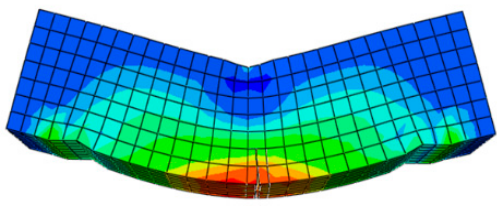

Extend the first crack of concrete (stage 2) when the external load reached $54.69 \%$ of the peak load.

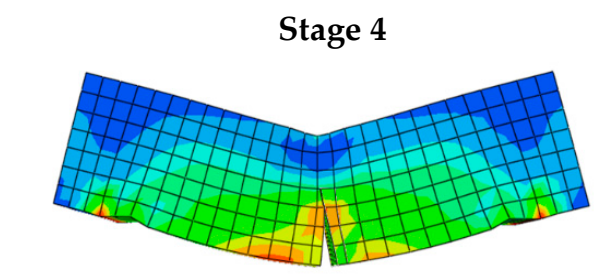

Extend the first crack of concrete (stage 3) when the external load reached $66.93 \%$ of the

Extend the first crack of concrete (stage 4) when peak load.

the external load reached $80.22 \%$ of the peak load.

\section{Stage 5}

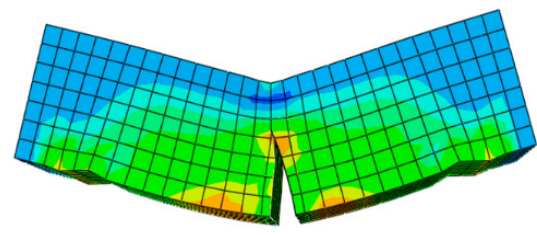

Extend the first crack of concrete (stage 5) when the external load reached $94.18 \%$ of the peak load.

\section{CFRP Delamination}

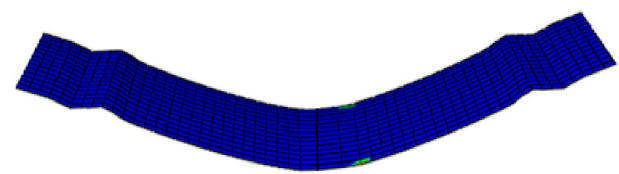

FRP delamination started when the external load reached $96.24 \%$ of the peak load.

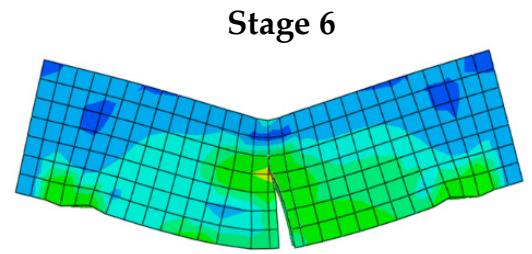

Stage 7

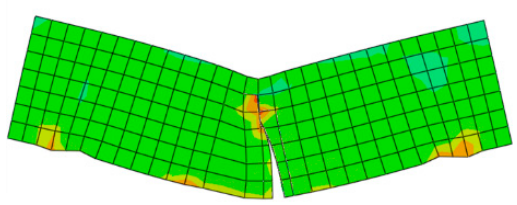

Extend the first crack of concrete (stage 6) Extend the first crack of concrete (stage 7) when when the external load reached $96.43 \%$ of the the external load reached $96.45 \%$ of the peak load. peak load.

Figure 9. Cont. 


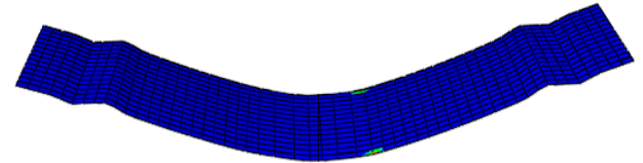

FRP delamination when the external load reached $96.43 \%$ of the peak load.

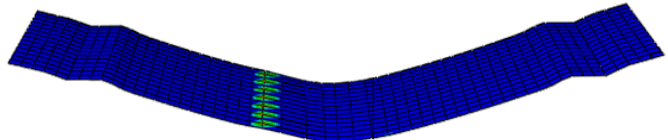

FRP delamination when the external load reached $96.45 \%$ of the peak load.

(a) The events of simulation loadings

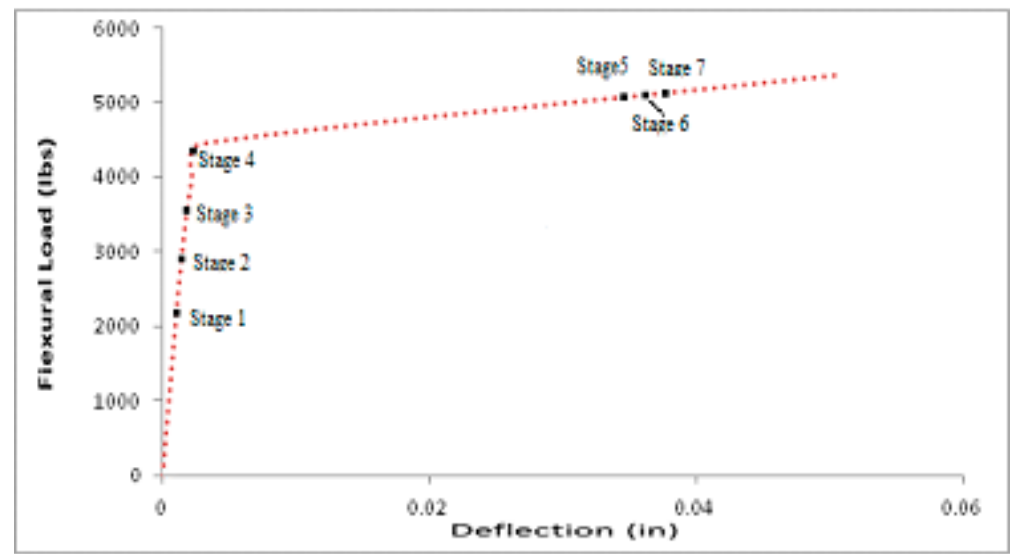

(b) The stages of concrete crack

Figure 9. Numerical flexural response of FRP strengthened concrete beams and the stages of concrete crack at $180{ }^{\circ} \mathrm{C}$. (a) The events of simulation loadings; (b) The stages of concrete crack.

As demonstrated in Figure 9, the first concrete crack started when the external load reached $41.88 \%$ of the peak load. There is no rupture of FRP, and the FRP delamination started when the external load reached $96.24 \%$ of the peak load.

Likewise, when compared the simulated and experimental flexural load and mid-span deflection of FRP strengthened concrete beams at $180{ }^{\circ} \mathrm{C}$, the experimental results of flexural load were about $20 \%$ less than the numerical results, which means the finite element model has been successful in prediction FRP strengthened concrete beam failure load.

The cohesive strength decreases when the temperature increases see Tables 3, 6 and 8 . The failure changed above the FRP transition temperature from failure in the concrete near the interface with the adhesive to failure exactly in the interface in between the concrete and the adhesive.

The maximum principal stress of concrete reached the input Max. Principal stress of concrete $2.813 \mathrm{MPa}$ (408 psi) at crack, then gradually increase until the peak load. Because after the onset of the crack in concrete, stress at the crack tip intends to go infinite and this is known as stress singularity at the crack tip. Therefore, in our simulations, we predict larger max principal stress values than input.

When the first crack shows up on the concrete surface and starts to spread, the FRP strengthening sheet tries to prevent crack propagation. As a result of this resistance, an extremely large max principle stress values will generate. See Table 9 for the comparison of failure load and first rupture beginning for FRP strengthened concrete beams at RT, $100{ }^{\circ} \mathrm{C}$ and $180{ }^{\circ} \mathrm{C}$.

Table 9. Comparison of failure load and first rupture beginning for FRP strengthened concrete beams at RT, $100{ }^{\circ} \mathrm{C}$ and $180{ }^{\circ} \mathrm{C}$.

\begin{tabular}{|c|c|c|}
\hline $\operatorname{Temp}{ }^{\circ} \mathrm{C}$ & Peak Load KN, (lbs) & First Rupture of FRP Beginning \\
\hline RT & $24.52 \mathrm{KN},(5512.6 \mathrm{lbs})$ & $99.63 \%$ of the peak load \\
\hline $100^{\circ} \mathrm{C}$ & $24.29 \mathrm{KN},(5461 \mathrm{lbs})$ & no rupture \\
\hline $180^{\circ} \mathrm{C}$ & 23.91KN, (5375 lbs) & no rupture \\
\hline
\end{tabular}


We noted that the flexural strength decreases with temperature rise for FRP strengthened concrete beams. The maximum flexural load of $100{ }^{\circ} \mathrm{C}$ decreased about $1 \%$ for the maximum flexural load of RT. The maximum flexural load of $180{ }^{\circ} \mathrm{C}$ decreased about $2 \%$ for the maximum flexural load of RT.

\subsection{FRP Strengthened Concrete Columns at Room Temperature (RT)}

By running the ABQUS-CAE software, the pressure began to increase by steps until the failure occurred. Figure 10 shows the crack pattern at peak load. The way of FRP rupture in the simulation was similar to the mode that was observed during the experimental tests (Figure 11).

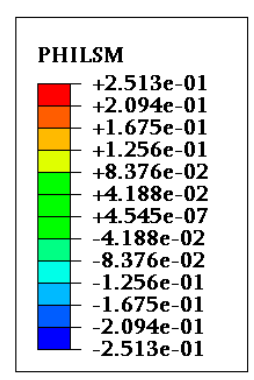

(a) Crack in (Concrete +FRP)
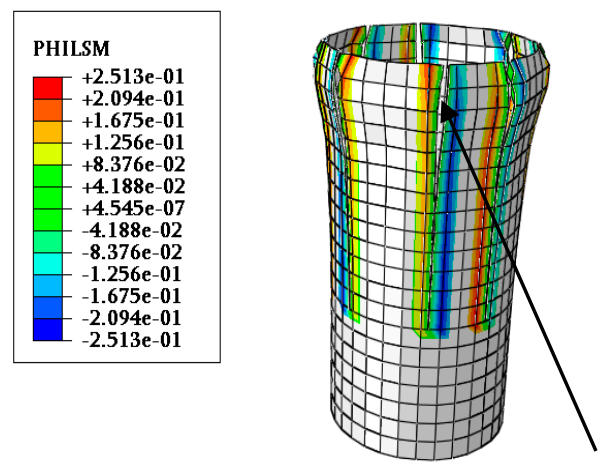

(b) Crack propagation Rupture in CFRP

PHILSM: Signed distance function to describe the crack surface

Figure 10. Crack propagation of FRP strengthened concrete column at peak load (RT).

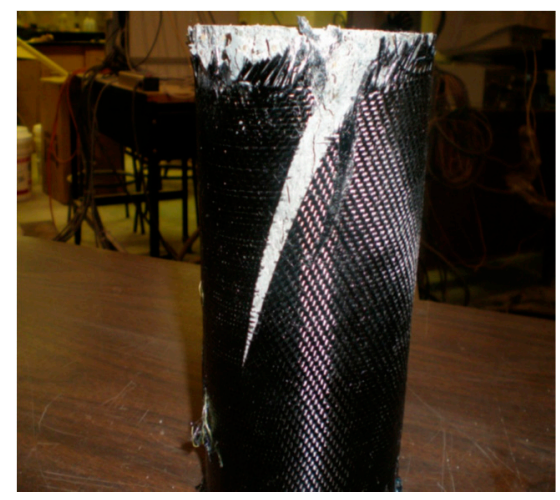

Figure 11. FRP rupture at experimental tests. Elarbi, 2011 [2].

At RT, the crack of CFRP started at $96.94 \%$ of the peak load. By comparing the simulated and experimental compressive load and mid-span deflection of FRP strengthened concrete columns at RT, the numerical results of compressive load was about $0.99 \%$ less than experimental results, which means the finite element model has been successful in prediction FRP strengthened concrete column failure load.

At $100{ }^{\circ} \mathrm{C}$, the crack of concrete started first, and after that, at the end of load ( $100 \%$ load), the crack of CFRP occurred. The cohesive strength decreases when the temperature increases see Tables 3 and 6. The failure changed under the FRP transition temperature from failure in the concrete near the interface with the adhesive to failure exactly in the interface in between the concrete and the adhesive. As well as, when the simulated and experimental compressive load and mid-span deflection of FRP strengthened concrete columns at $100{ }^{\circ} \mathrm{C}$ were compared, the experimental results of compressive load was about $0.61 \%$ less than numerical results, which means the finite element model has been successful in prediction FRP strengthened concrete column failure load. 
At $180{ }^{\circ} \mathrm{C}$, the crack of concrete started first, after that at $97.48 \%$ of the peak load the crack of CFRP started. For the cohesive strength decreases when the temperature increases, see Tables 3, 6 and 8. The failure changed under the FRP transition temperature from failure in the concrete near the interface with the adhesive to failure exactly in the interface in between the concrete and the adhesive. When compared the simulated and experimental compressive load and mid-span deflection of FRP strengthened concrete columns at $180^{\circ} \mathrm{C}$, the numerical results of compressive load was about $7 \%$ less than experimental results, which means the finite element model has been successful in the prediction of FRP strengthened concrete column failure load. The Table 10 shows the comparison of failure load and first rupture beginning for FRP strengthened concrete columns at RT, $100{ }^{\circ} \mathrm{C}$ and $180^{\circ} \mathrm{C}$.

Table 10. Comparison of failure load and first rupture beginning for FRP strengthened concrete columns at RT, $100{ }^{\circ} \mathrm{C}$ and $180^{\circ} \mathrm{C}$.

\begin{tabular}{ccc}
\hline Temp ${ }^{\circ} \mathrm{C}$ & Peak Load KN, (lbs) & First Rupture of FRP Beginning \\
\hline RT & $387.54 \mathrm{KN},(87,122.65 \mathrm{lbs})$ & $96.94 \%$ of the peak load \\
$100^{\circ} \mathrm{C}$ & $491.9 \mathrm{KN},(110,584.1 \mathrm{lbs})$ & at the peak load \\
$180^{\circ} \mathrm{C}$ & $279.49 \mathrm{KN},(62,831.85 \mathrm{lbs})$ & $97.48 \%$ of the peak load \\
\hline
\end{tabular}

The maximum compressive load of $100^{\circ} \mathrm{C}$ increased about $27 \%$ for the maximum compressive load of RT. The maximum compressive load of $180^{\circ} \mathrm{C}$ decreased about $39 \%$ for the maximum compressive load of RT. This is the same as the experimental results [2]. This concludes that the high temperature $180^{\circ} \mathrm{C}$ has an adverse influence on the compressive strength of the specimens.

\section{Conclusions}

The following conclusions can be drawn from this research:

(1) The FE results are in generally agreement with the experimental results for all temperatures. The maximum discrepancy was $27 \%$.

(2) At room temperature, the FRP strengthened beams showed predominately flexural cracks in concrete, followed by a brief FRP delamination prior to FRP rupture. The first rupture of FRP started when the external load reached $99.63 \%$ of the peak load.

(3) When the temperature is raised to $100{ }^{\circ} \mathrm{C}$ and $180{ }^{\circ} \mathrm{C}$, the FRP strengthened beams showed predominately flexural cracks in concrete, followed by a brief FRP delamination. As the temperature rises, a delay of FRP delamination has been observed.

(a) The maximum flexural load of $100^{\circ} \mathrm{C}$ decreased about $1 \%$ for the maximum flexural load of RT, these results suggest that the FRP strengthened concrete beams at $100{ }^{\circ} \mathrm{C}$, flexural strength weaker than FRP strengthened concrete beams at RT.

(b) The maximum flexural load of $180^{\circ} \mathrm{C}$ decreased about $2 \%$ for the maximum flexural load of RT. These results suggest that the FRP strengthened concrete beams at $180^{\circ} \mathrm{C}$, flexural strength weaker than FRP strengthened concrete beams at RT and $100{ }^{\circ} \mathrm{C}$.

(c) This concludes that the flexural strength decreases with temperature rise for FRP strengthened concrete beams.

(4) The FRP strengthened columns showed compression cracks in concrete and FRP rupture. The crack of FRP started at $96.94 \%$ of the peak load at room temperature. At the end of load ( $100 \%$ load), the crack of FRP occurred when the temperature is raised to $100^{\circ} \mathrm{C}$. While at $180^{\circ} \mathrm{C}$ the crack of CFRP started at $97.48 \%$ of the peak load. The crack of FRP increased expansion at $180^{\circ} \mathrm{C}$ than $100^{\circ} \mathrm{C}$, in the way of FRP rupture in the simulation was similar to the mode that was observed during the experimental tests. 
(a) The maximum compressive load of $100{ }^{\circ} \mathrm{C}$ increased about $27 \%$ for the maximum compressive load of RT. These results suggest that the FRP strengthened concrete columns at $100{ }^{\circ} \mathrm{C}$, compressive strength stronger than FRP strengthened concrete columns at RT.

(b) The maximum compressive load of $180{ }^{\circ} \mathrm{C}$ decreased about $39 \%$ for the maximum compressive load of RT. This is the same as the experimental results [2]. This concludes that the high temperature $180^{\circ} \mathrm{C}$ has an adversely influence on the compressive strength of the specimens.

(5) The thickness of FRP wrapping was $0.25 \mathrm{~mm}(0.01 \mathrm{in})$ in this study. I recommend in future, use thick of FRP wrapping more than $0.25 \mathrm{~mm}(0.01 \mathrm{in})$ for beams and columns to withstand high temperature $\left(100^{\circ} \mathrm{C}\right.$ and $\left.180{ }^{\circ} \mathrm{C}\right)$.

(a) Also, it should be noted that the above mentioned findings are based on the cohesive behavior formulation (the cohesive traction-separation damage model) was use to the characterization of damage evaluation at the interface between concrete and FRP. In future, the virtual crack closure technique (VCCT) that is also available in the ABAQUS-CAE is recommended to be utilized and compared to the results obtained from the cohesive behavior formulation.

Author Contributions: Conceptualization, B.G., and H.-C.W.; Methodology, B.G., and H.-C.W.; Software, B.G.; Formal Analysis, B.G.; Investigation, H.-C.W.; Experiments; A.E. and H.-C.W.; Writing, B.G. All authors have read and agreed to the published version of the manuscript.

Funding: This research received no external funding.

Conflicts of Interest: The authors declare no conflict of interest.

\section{References}

1. Banea, M.D.; da Silva, L.F.M. Adhesively Bonded Joints in Composite Materials: An overview. Available online: https://journals.sagepub.com/doi/pdf/10.1243/14644207JMDA219 (accessed on 28 January 2020).

2. Elarbi, A. Durability Performance of FRP Strengthened Concrete Beams and Columns Exposed to Hydrothermal Environment. Ph.D. Dissertation, Wayne State University, Detroit, MI, USA, 2011.

3. Elarbi, A.; Wu, H.-C. Flexural Behavior of Epoxy under Accelerated Hygrothermal Conditions. Fibers 2017, 5 , 25. [CrossRef]

4. Foster, S.K.; Bisby, L.A. Fire Survivability of External Bonded FRP Strengthening Systems. J. Compos. Constr. 2008, 12, 553-561. [CrossRef]

5. Taljsten, B. FRP Strengthening of Existing Concrete Structures; Design Guidelines; Lulea University Printing Office: Lulea, Sweden, 2002.

6. Park, S. Durability of Adhesive Joints Between Concrete and FRP Reinforcement in Aggressive Environments. Ph.D. Dissertation, The University of Texas at Austin, Austin, TX, USA, August 2005.

7. Vpgel, H.; Svecova, D. Thermal Compatibility and Bond Strength of FRP Reinforcement in Prestressed Concrete Applications. J. Compos. Constr. 2007, 11, 459-468.

8. Gheorghiu, C.; Labossiere, P.; Raiche, A. Environmental Fatigue Static Behavior of RC Beams with Carbon-Fiber-Reinforced Polymer. J. Compos. Constr. 2004, 8. [CrossRef]

9. Bond of Reinforcement in Concrete; State-of-art Report, Federation International du béton; The International Federation for Structural Concrete: Lausanne, Switzerland, 2000; ISBN 2-88394-050-9.

10. Fyfe Product Data Sheet: Tyfo_S Saturant Epoxy, Fyfe Co. LLC. 2011. Available online: http://www.fyfeco. com/products/pdf/tyfosepoxy.pdf (accessed on 28 January 2020).

11. Matthews, F.L.; Davies, G.A.O.; Hitchings, D.; Soutis, C. Finite Element Modeling of Composite Materials and Structures; Woodhead Publishing Ltd.: Sawston, UK, 2000.

12. Moës, N.; Dolbow, J.; Belytschko, T. A Finite Element Method for Crack Growth without Remeshing. Inter. J. Numerical Methods Eng. 1999, 46, 131-150. [CrossRef]

13. Extended Finite Element Method. Available online: http://en.wikipedia.org/wiki/Extended_finite_element_ method (accessed on 28 January 2020). 
14. Di Tommaso, A.; Neubauer, U.; Pantuso, A.; Rostasy, F.S. Behavior of Adhesively Bonded Concrete-CFRP Joints at Low and High Temperatures. Mech. Compos. Mater. 2001, 37, 327-338. [CrossRef]

15. Klamer, E.L.; Hordijk, D.A.; Kleinman, C.S. Debonding of CFRP Laminates Externally Bonded to Concrete Specimens at Low and High Temperatures. In Proceedings of the third International Conference on FRP Composites in Civil Engineering, Miami, FL, USA, 13-15 December 2006; pp. 35-38.

16. Malvar, L.J.; Joshi, N.R.; Beran, J.A.; Novinson, T. Environmental Effects on The Short-Term Bond of Carbon Fiber-Reinforced Polymer CFRP Composites. J Compos. Constr. 2003, 7, 58-63. [CrossRef]

17. Tadeu, A.J.B.; Branco, F.J.F.G. Shear Tests of Steel Plates Epoxy-Bonded to Concrete under Temperature. J. Mater. Civ. Eng. 2000, 12, 74-80. [CrossRef]

18. Obaidat, Y.; Heyden, S.; Dahlblom, O. The Effect of CFRP and CFRP/Concrete Interface Models When Modelling Retrofitted RC Beams with FEM. Compos. Struct. 2010, 92, 1391-1398. [CrossRef]

19. Mohammadi, T.; Wan, B.; Harries, K. Intermediate Crack Debonding Model of FRP Strengthened Concrete Beams Using XFEM. In Proceedings of the Simulia Community Conference, Vienna, Austria, 22 May 2013.

20. Finite Element Analysis Lecture\#3; Class Notes, Abaqus Software; Civil Engineering Department, Lawrence Technology University: Southfield, MI, USA, 2010.

21. Michal, S.; Andrzej, W. Calibration of the CDP model parameters in Abaqus. In Proceedings of the World Congress on Advances in Structural Engineering and Mechanics (ASEM15), Incheon, Korea, 25-29 August 2015.

22. Mikamia, C.; Wu, H.-C.; Elarbi, A. Effect of Hot Temperature on Pull-Off Strength of FRP Bonded Concrete. Constr. Build. Mater. 2015, 91, 180-186. [CrossRef]

23. Dri, F.; Restrepo, D. Characterization of the Mode I Fracture Energy of Adhesive Joints; Course Materials CE 595-Project 2; Civil Engineering Department, Purdue University: West Lafayette, IN, USA, 2011.

24. Finite Element Analysis Lecture\#5; Class Notes, Abaqus Software; Civil Engineering Department, Lawrence Technology University: Southfield, MI, USA, 2010.

25. Ezekiel, S.; Xiao, R.; Chin, C. Constitutive Model for Compressive Strength and Elastic Modulus for Concrete under Elevated Temperature. In Proceedings of the Structures Congress 2013: Bridging Your Passion with Your Profession, Pittsburgh, PL, USA, 2-4 May 2013; pp. 2916-2925.

26. Guo, Z.; Shi, X. Experiment and Calculation of Reinforced Concrete at Elevated Temperatures; Elsevier Inc.: Amsterdam, The Netherlands, 2011.

27. Venkatesh, K. Properties of Concrete at Elevated Temperatures; Michigan State University: East Lansing, MI, USA, 2014.

28. Advanced Materials $\quad$ Epibond ${ }^{\circledR} \quad 100 \quad$ A/B $\quad$ High-Temperature $\quad$ Epoxy Structural Adhesive. Available online: http://www.huntsman.com/corporate/Media\%20Library/a_ MC4EE584E6EFA7273E040EBCD2C6B19E9/Innovation_MC4EE584E960B7273E040EBCD2C6B19E9/New\% 20HighPerformance_ME4D57E08A6F79FC2E040EBCD2B6B3510/files/Epibond\%20100\%20AB_US_e.pdf (accessed on 28 January 2020).

(C) 2020 by the authors. Licensee MDPI, Basel, Switzerland. This article is an open access article distributed under the terms and conditions of the Creative Commons Attribution (CC BY) license (http://creativecommons.org/licenses/by/4.0/). 